\title{
Incidental Skeletal Findings on Sodium-fluoride Positron Emission Tomography: A Collection of Benign Tumors
}

\author{
Sodyum-florür Pozitron Emisyon Tomografisinde Insidental Iskelet Sistemi Bulguları: \\ Benign Tümörlerden Bir Derleme
}

\author{
(1) Nada Almenieir1,2, (1) Marc Hickeson', (1) Javier Novales-Diaz', (1) Vilma Derbekyan', (1) Gad Abikhzer³ \\ IMcGill University Health Center, Department of Nuclear Medicine, Montreal, Canada \\ 2King Saud University, Department of Radiology and Medical Imaging, Riyadh, Saudi Arabia \\ 3jewish General Hospital, Departement of Nuclear Medicine, Montreal, Canada
}

\begin{abstract}
Sodium-fluoride (NaF) positron emission tomography (PET) is a sensitive method to detect altered bone mineralization. Its increasing use in routine clinical practice for metastatic bone disease has also resulted in the detection or characterization of incidental benign bone lesions. A spectrum of NaF PET scan cases with benign bone tumors are presented in this article, including whole body PET bone scan and selected PET/computed tomography (CT), $C T$, or magnetic resonance imaging (MRI) of the region of interest. The reader will be able to improve their knowledge related to the clinical presentation of these entities, some are rare and recognize based on NaF PET and CT/MRI patterns by reviewing these cases.

Keywords: NaF, sodium-fluoride PET, benign bone lesions
\end{abstract}

\section{Öz}

Sodyum-florür (NaF) pozitron emisyon tomografisi (PET), kemik mineralizasyonu değişimini tespit etmek için hassas bir yöntemdir. Metastatik kemik hastalığı için rutin klinik uygulamada artan kullanımı aynı zamanda insidental iyi huylu kemik lezyonlarının saptanması veya karakterizasyonu ile de sonuçlanmıştır. Bu makalede, tüm vücut PET kemik taraması ve ilgili bölgenin seçilmiş PET/bilgisayarlı tomografisi (BT), BT veya manyetik rezonans görüntüleme (MRG) dahil, benign kemik tümörlerinin NaF PET ile tarandığı olguların bir spektrumu sunulmuştur. Okuyucu, bu olguların klinik prezentasyonuyla ilgili bilgilerini geliştirebilecek, bazıları nadir olan bu olguları gözden geçirerek, NaF PET ve BT/MRG modellerine dayanarak taniyabilecektir.

Anahtar kelimeler: NaF, sodyum-florür PET, iyi huylu kemik lezyonları

Address for Correspondence: Nada Almenieir MD, McGill University Health Center, Department of Nuclear Medicine, Montreal, Canada Phone: +8573526301 E-mail: n.almenieir@gmail.com ORCID ID: orcid.org/0000-0002-6377-0542 Received: 07.12.2019 Accepted: 26.04.2020 

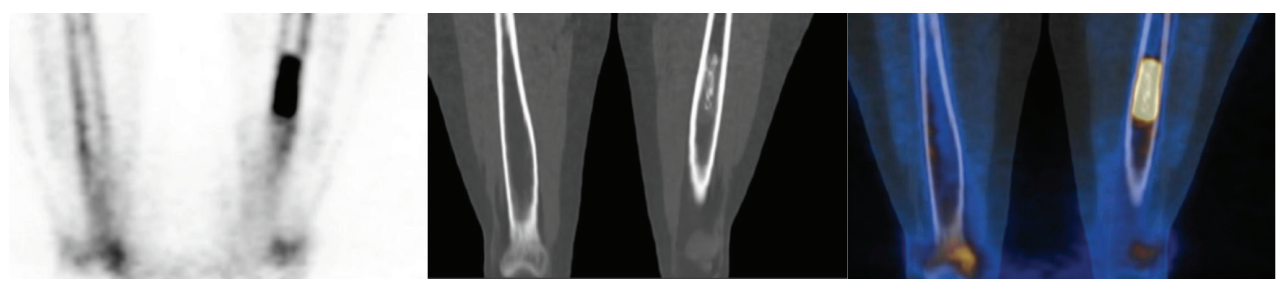

Figure 1. Enchondroma: A 29-year-old female patient with breast cancer. Sodium-fluoride (NaF) positron emission tomography/computed tomography (PET/CT) images demonstrated segmental intensely increased uptake in the mid diaphysis of the left femur, with classic "rings and arcs" calcifications in the CT.
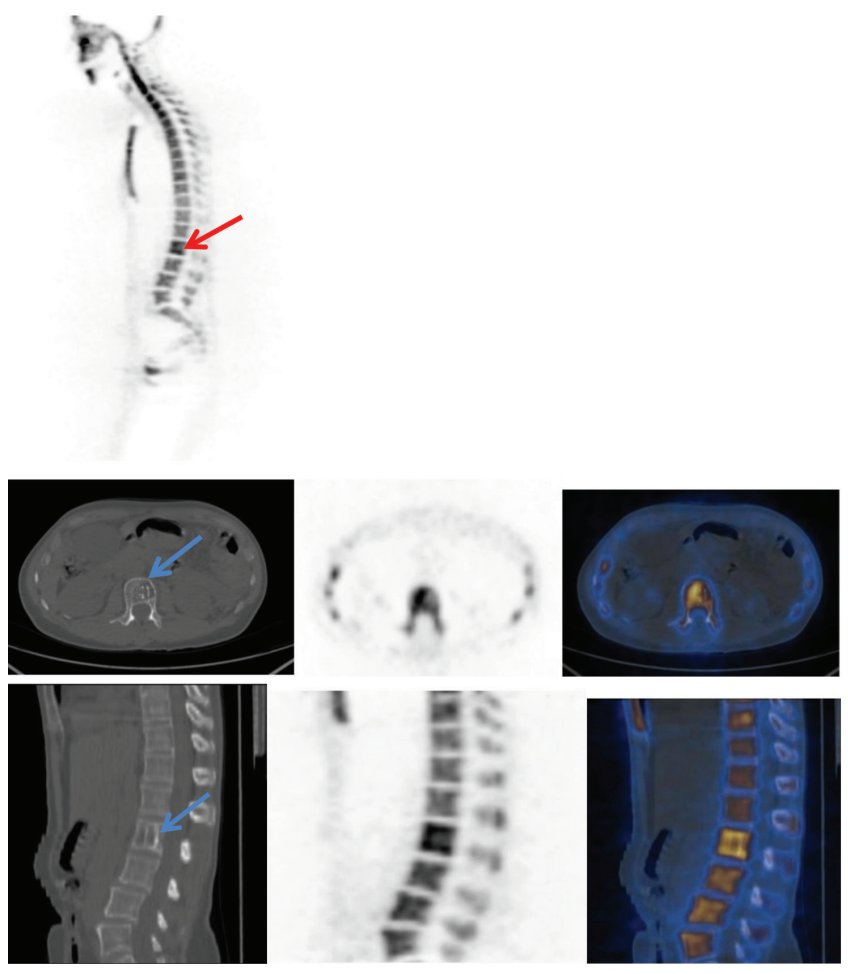

Figure 2. Hemangioma: A 50-year-old female patient with breast cancer. NaF PET images demonstrated mild heterogenous uptake in the L2 vertebral body, which upon closer inspection is actually decreased in the bone lesion. CT images demonstrated thickened vertebral trabeculae with axial images showing the typical "polka dot" sign of intraosseous hemangioma (1).
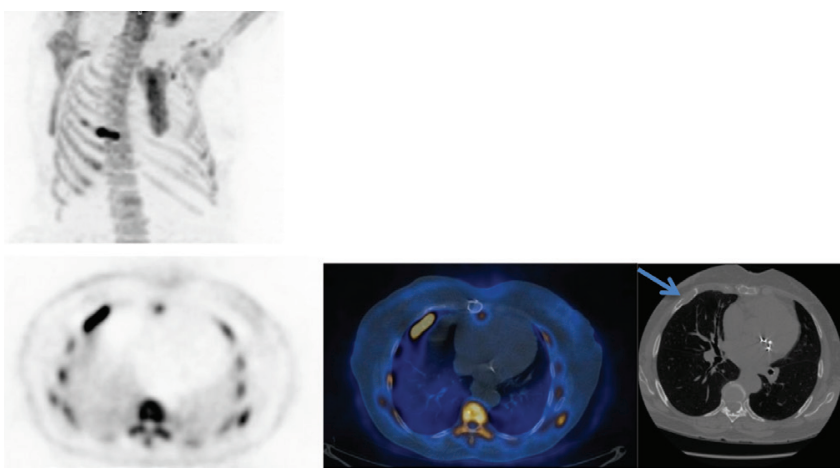

Figure 3. Fibrous dysplasia: A 77-year-old female patient with breast cancer. NaF PET images demonstrated segmental uptake in the right $5^{\text {th }}$ rib. A misregistered activity was noted on hybrid fusion due to patient motion in the expansile lesion with cortical disruption on CT. Biopsy was performed, which demonstrated fibrous dysplasia. Fibrous dysplasia is the most common benign rib lesionn (2).
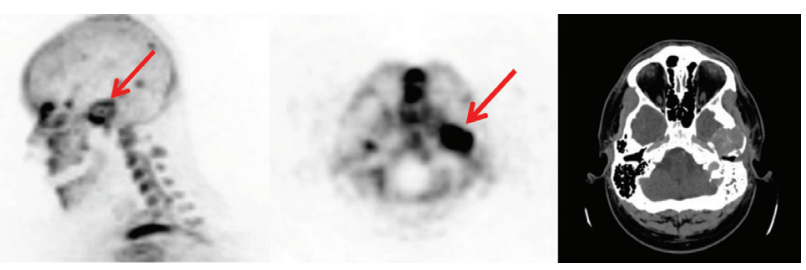

Figure 4. Chondroblastoma: A 42-year-old male patient with new onset hearing loss in the left ear. NaF PET images demonstrated an intensely increased activity in the region of the left temporal bone. CT images demonstrated an extra-axial mass in the left medial cranial fossa causing erosion of the temporal bone, mastoid bone, middle ear ossicles, and temporal side of the left temporomandibular joint. Biopsy of the lesion showed chondroblastoma. Chondroblastomas are rare primary bone tumors, occurring predominantly in young patients $(<20$ years of age), with an overall male predilection (3), which are usually three-phase positive on conventional bone scan using tc99m- methylene diphosphonate, and can demonstrate increased fluorodeoxyglucose uptake, thus differentiating these lesions from malignancy is important. 


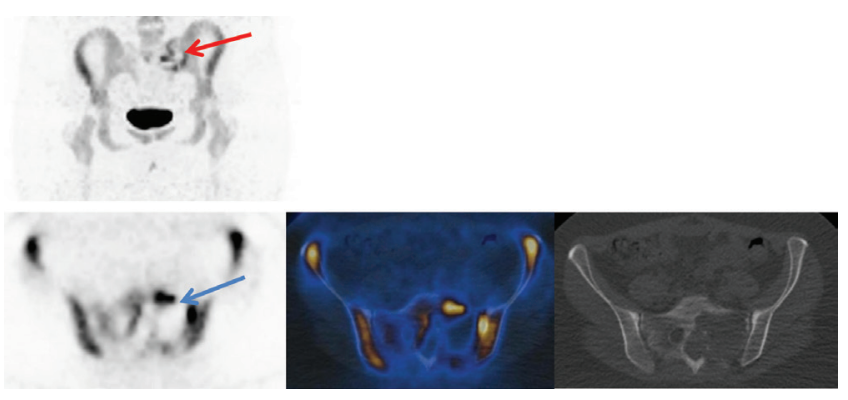

Figure 5. Giant cell tumor (GCT): A 32-year-old female patient with back pain. NaF PET images demonstrated a rim of mild to moderate heterogeneous increased activity with a photopenic center in an expansile radiolucent lesion in the left sacrum. Biopsy demonstrated a GCT. GCTs are usually solitary, involving 4\%-9\% of the sacrum (4).
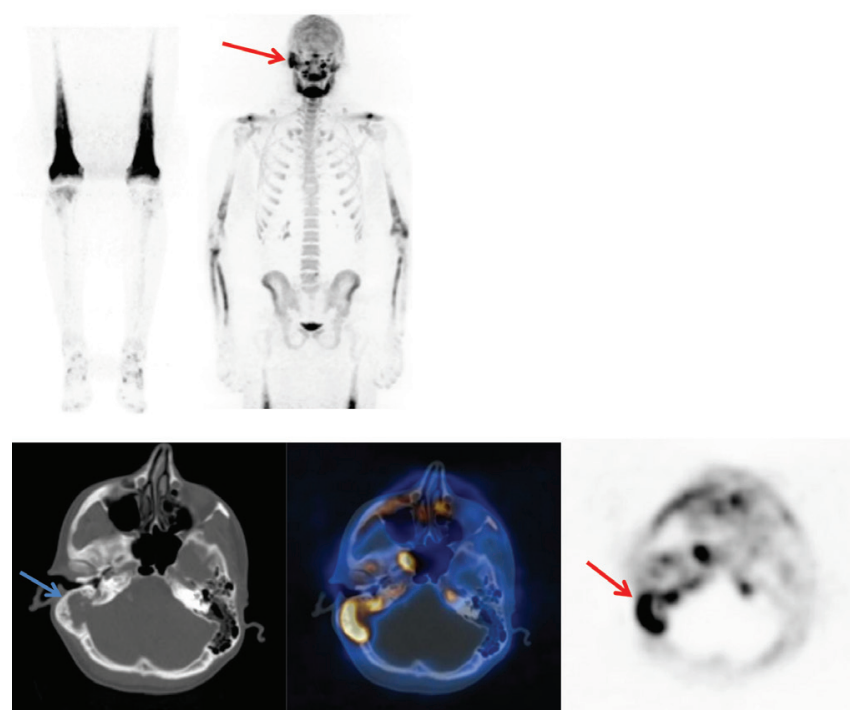

Figure 6. Langerhans' cell histiocytosis (LCH): A 31-year-old male patient with incidental lytic skull lesion on head imaging. NaF PET images demonstrated an increased uptake in the right mastoid, diffusing in the mandible and long bones such as the distal humeri, radius, and ulnar, as well as the distal two thirds of femurs. CT of the head demonstrated a large expansile lytic lesion involving the right mastoid. Biopsy of the left maxillary gums showed Langerhans cell proliferation with positive BRAF staining. LCH is a disease with abnormal histiocytes proliferation, and subsequent various organs accumulation. The skeleton is the most commonly involved organ system in LCH, involving 50\% of the skull (5).

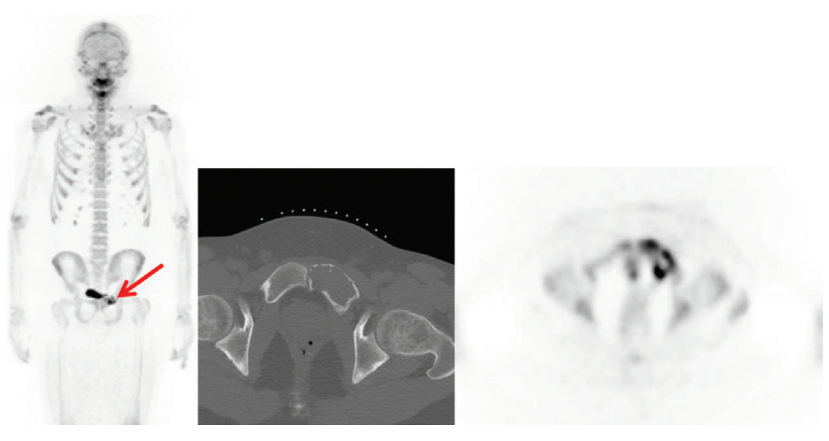

Figure 7. Desmoplastic fibroma: A 30-year-old male patient with a 1-year history of left hip/groin pain. NaF PET images demonstrated heterogeneous tracer uptake within the cortex of an expansile osseous lesion in the left superior pubic ramus. After the CT-guided biopsy which showed desmoplastic fibroma, the lesion was resected. Desmoplastic fibromas are extremely rare bone tumors that are histologically identical to soft tissue desmoid tumors (6).
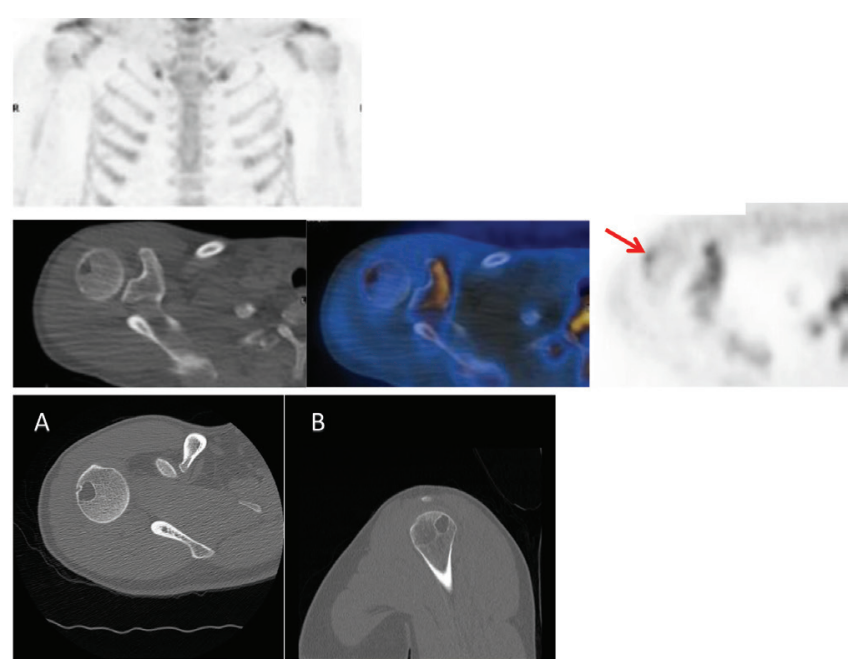

Figure 8. Intraosseous lipoma: A 35 year-old male patient presented with right shoulder sports injury, which led to an incidental $1.4 \times 1.4 \mathrm{~cm}$ lucent osseous lesion in the subcortical lateral right humeral epiphysis with internal fat density (HU: -90), thin sclerotic margin, and narrow transition zone as demonstrated on diagnostic $\mathrm{CT}$ images ( $\mathrm{A}$ and $\mathrm{B}$ ). NaF PET demonstrated only minimally increased focal uptake at the site of the lucency in the right humeral head. No further investigation or treatment was deemed necessary as intraosseous lipomas that do not affect bone stability are treated conservatively (7). 


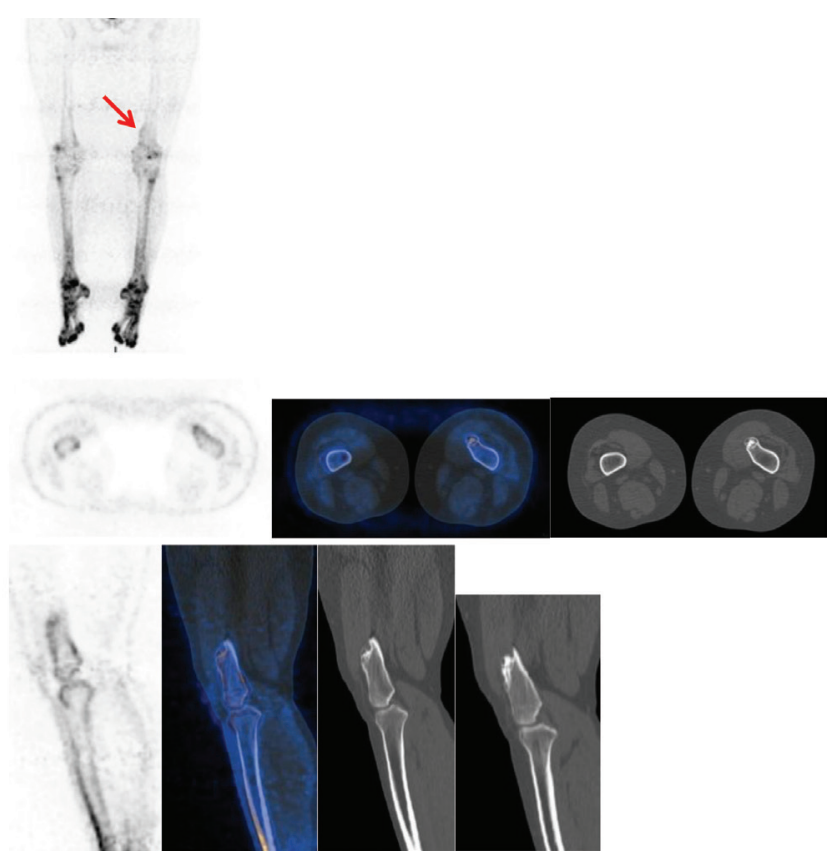

Figure 9. Osteoid osteoma: A 28 year-old male patient with indolent right shoulder pain, which worsens at night and improves with non-steroidal anti-inflammatories. NaF PET images demonstrate focal intense increased uptake in the glenoid fossa of the right scapula, associated with sclerosis of the right glenoid and radiolucent nidus and central mineralization. Patient underwent radiofrequency ablation of the lesion, which led to symptom improvement (8).

\section{Ethics}

Informed Consent: Informed consent was waived.

Peer-review: Externally and internally peer-reviewed.

\section{Authorship Contributions}

Concept: N.A., G.A., Design: N.A., G.A., Data Collection or Processing: N.A., G.A., Analysis or Interpretation: N.A., M.H., J.N.D., V.D., G.A., Literature Search: N.A., Writing: N.A.

Conflict of Interest: No conflict of interest was declared by the authors.

Financial Disclosure: The authors declared that this study received no financial support.

\section{References}

1. Persaud T. The polka-dot sign. Radiology 2008;246:980-981.

2. Rubin AN, Byrns K, Zhou D, Freedman L. Fibrous Dysplasia of the Rib: AIRP Best Cases in Radiologic-Pathologic Correlation. Radiographics 2015;35:2049-2052.

3. Erickson JK, Rosenthal DI, Zaleske DJ, Gebhardt MC, Cates JM. Primary treatment of chondroblastoma with percutaneous radio-frequency heat ablation: report of three cases. Radiology 2001;221:463-468.

4. Murphey MD, Nomikos GC, Flemming DJ, Gannon FH, Temple HT, Kransdorf MJ. From the archives of AFIP. Imaging of giant cell tumor and giant cell reparative granuloma of bone: radiologic-pathologic correlation. Radiographics 2001;21:1283-1309.

5. David R, Oria RA, Kumar R, Singleton EB, Lindell MM, Shirkhoda A, Madewell JE. Radiologic features of eosinophilic granuloma of bone. AJR Am J Roentgenol 1989;153:1021-1026.

6. Frick MA, Sundaram M, Unni KK, Inwards CY, Fabbri N, Trentani F, Baccini $\mathrm{P}$, Bertoni F. Imaging findings in desmoplastic fibroma of bone: distinctive T2 characteristics. AJR Am J Roentgenol 2005;184:1762-1767.

7. Campbell RS, Grainger AJ, Mangham DC, Beggs I, Teh J, Davies AM. Intraosseous lipoma: report of 35 new cases and a review of the literature. Skeletal Radiol 2003;32:209-222.

8. Chai JW, Hong SH, Choi JY, Koh YH, Lee JW, Choi JA, Kang HS. Radiologic diagnosis of osteoid osteoma: from simple to challenging findings. Radiographics 2010;30:737-749. 